\title{
Musculoskeletal analysis of masticatory system arising from malocclusion: literature review
}

\author{
CASARIN, C. A. S. ${ }^{1,2 *}$, PALMA, R. K. ${ }^{3}$, ARSA, G. ${ }^{4}$, ANDRADE, E. L. ${ }^{1}$, \\ LEITE, G. S. ${ }^{1}$, BOCALINI, D. S. ${ }^{1,2}$, SERRA, A. J. ${ }^{1,3}$, SUZUKI, F. S. ${ }^{1,2}$ and \\ CARIA, P. H. F. ${ }^{5}$
}

\author{
${ }^{1}$ Department of Physical Education, Universidade Nove de Julho - UNINOVE, \\ Avenida Doutor Adolfo Pinto, 109, CEP 01156-050, São Paulo, SP, Brazil \\ ${ }^{2}$ Post-graduation Program in Physical Education, Universidade São Judas Tadeu - USJT, \\ Rua Taquari, 546, Mooca, CEP 03166-000, São Paulo, SP, Brazil \\ ${ }^{3}$ Post-graduation Program in Rehabilitation Science and Biophotonic, Universidade Nove de Julho - UNINOVE, \\ Avenida Doutor Adolfo Pinto, 109, CEP 01156-050, São Paulo, SP, Brazil \\ ${ }^{4}$ Post-graduation Program in Physical Education, Universidade Federal de Mato Grosso - UFMT, Avenida \\ Fernando Correa da Costa, 2367, CEP 08740-540, Cuiabá, MS, Brazil \\ ${ }^{5}$ Department of Morphology, Piracicaba Dental School, Universidade Estadual de Campinas - UNICAMP, \\ Avenida Limeira, 901, CEP 13414-903, Piracicaba, SP, Brazil \\ *E-mail: cezarcasarin.x@gmail.com
}

\begin{abstract}
Introduction: The malocclusion can be defined as any change in the natural position of contact between the teeth and the arcades format that affects the morphofunctional architecture of the masticatory system of individuals affected by such condition. The aim of this study was to review the literature and to investigate the morphofunctional changes of the mandible and masticatory muscles as result of malocclusion. Material and Methods: This study consisted of a systematic review and the search for the theoretical composition was performed in the Lilacs, PubMed and Scielo database using as descriptors the words Malocclusion, Mandible, Masticatory Muscles and as filters the words Abstract Available, English Language, Humans, Rats. Results: This research allowed the authors to assert that the occlusal alterations are capable of causing morphological and functional modifications in the mandible and masticatory muscles. Conclusion: Given these aspects, it was possible to highlight the malocclusion as an aggravating factor at quality of life.
\end{abstract}

Keywords: masseter muscle, temporalis muscle, bone density, malocclusion.

\section{Introduction}

The malocclusion is considered a common oral disorder found in the population, which can directly affect the active lives of these individuals (ZHANG, MCGRATH and HÄGG, 2006). The occlusal changes may be caused by the morphological disharmony on tooth position and on the shape of the dental arches. Show varied causes and factors such as postural disorders, parafunctions, psychological aspects, propioceptive changes which affect the masticatory system causing overload on the maxillo-mandibular elements, generating an impact on the structure, density and micro-architecture of the skeletal muscle tissue of the mandible (MAVROPOULOS, BRESIN and KILIARIDIS, 2004).

Although it is not considered a pathology, malocclusion allied to muscle pain and discomfort can cause organic, social and psychological imbalance in individuals with this condition, making it a public health problem that affects large part of the population (KUNII, YAMAGUCHI, AOKI et al., 2008).

The abnormally decrease of habitual masticatory activity or the poor and frequent execution of mandibular movements acts negatively on the morphofunctional aspects of the masticatory system, which can cause reduction in bone mass in the maxillomandibular structures and dysfunction of the masticatory muscles (BANI and BERGAMINI, 2002; MAVROPOULOS, RIZZOLI and AMMANN, 2007) .

Such aspect may jeopardize the structure of bone tissue and can cause diseases such as osteopenia, osteoporosis, periodontitis, tooth loss and temporomandibular disorder (MAVROPOULOS, RIZZOLI and AMMANN, 2007; VLASIADIS, DAMILAKIS, VELEGRAKIS et al., 2008), and negatively act on the activity of mandible elevator muscles, primarily characterized by sensory and motor symptoms such as fatigue, pain and discomfort of these muscles, usually related to malocclusion (BRESIN and KILIARIDIS, 2002).

Given the relationship between malocclusion and the masticatory structures changes, this study aimed to analyze through the review of the literature, the morphofunctional alterations of the mandible and masticatory muscles resulting from malocclusion alterations.

\section{Material and Methods}

The present study consists of a systematic review. The most relevant original scientific studies analyzed in this research were from 1973 to 2015 . Previous bibliography to this period were 
discarded. The PubMed, Scielo, and Lilacs database were used to conduct a literature search using the following keywords: malocclusion, mandible, masticatory muscles. Forty-one articles were found that met these pre-requirements, however, was used a filter for the words Abstract Available, English Language, Humans, Rats. These, only twenty-nine were used.

From the malocclusion, the architecture of the muscles and bones of the masticatory system were analyzed.

\section{Results}

This research allowed the authors to assert that the occlusal alterations are capable of causing morphological and functional modifications in the microarchitecture musculoskeletal of the masticatory system. The changes resulting from mechanical effects and incidence of pain, generated in the structures of the stomatognathic system, with relation to the prevalence of temporomandibular disorders.

\section{Discussion}

In the last decade, the occlusal changes have occupied a prominent place in society as a risk factor to health of biologically susceptible individuals. These abnormalities were considered malefic by causing morphofunctional damages in masticatory system, reaching a significant percentage of the population negatively affecting quality of life of its carrier (ZHANG, MCGRATH and HÄGG, 2006; AZUMA, KOHZUKI, SAEKI et al., 2008).

Fact that has promoted the accomplishment of the study of Zhang, Mcgrath and Hägg (2006) that has investigated the impact caused by malocclusion on the lifestyle of the population and demonstrated the need of a comprehensive and accurate evaluation, with the use of instruments of valid and reliable data collection to avoid early diagnosis and unnecessary surgical procedures.

In another study, Azuma, Kohzuki, Saeki et al. (2008) considered the questionnaire Short Form 36 (SF-36) to verify the quality of life and Spielberger's State-Trait Anxiety Inventory Questionnaire (STAI) to assess the anxiety as a efficient diagnostic track, since the surgeries performed after the note of these questionnaires provided improvement in the quality of life and psychological condition of patients with occlusal problems.

The term dental occlusion is defined as a static relation of contact between the antagonist teeth (POSSELT, 1973). While the physiological occlusion has been defined as the one in which the set of forces that act on the teeth are in a state of equilibrium, keeping the health status and regular function among the teeth and supporting structures of the masticatory system (MOLINA, 1989).

Studies in both animals and humans showed that the teeth and assessoried tissues associated to the temporomandibular joint and mandible muscles collaborate interdependently to the balance of the masticatory process. While any change occurred to these structures induces abnormal modifications in musculoskeletal anatomy and physiology of the masticatory system (MIEHE, FANGHANEL, KUBEIN-MEESENBURG et al., 1999; DALE, 2001; WINARAKWONG, MURAMOTO, SOMA et al., 2004).

According to Casarin, Bocalini, Leite et al. (2015), any change in the activity of temporalis and masseter muscles of rats, from the malocclusion, regardless of intensity, may cause disruption in the architecture and consequently loss of masticatory function. Condition also found in humans (OHMURE, MIYAWAKI, NAGATA et al., 2008).

The bone is considered an extremely active tissue, because its metabolic activity involves predominantly the bone remodeling process, which is defined as a process of apposition, in which occurs a located removal of the old bone (reabsorption) and a replacement for newly composed tissue (HILL and ORTH, 1998). Fact that happens for the whole life of vertebrates, responsible for the remodeling of the skeleton and maintenance of morphological and functional integrity of the bones (MEGHJI, 1992; BROWN and JOSSE, 2002).

This biological phenomenon can become disordered in the mandible of humans and experimental animals when the malocclusion is installed. This pathology can reduce either the levels of bone density by inhibiting the process of apposition as speed up the process of remodeling, inhibiting reabsorption, which provides an increase of bone mass in a abnormally way (VLASIADIS, DAMILAKIS, VELEGRAKIS et al., 2008; AZUMA, KOHZUKI, SAEKI et al., 2008; CASARIN, BOCALINI, LEITE et al., 2015).

Skeletal muscles when active are initiators of bone apposition due to the tension exerted on the bone regions of insertion, which also occurs with the teeth that transmit tension to the bone tissue from their alveoli in the masticatory process (BRESIN and KILIARIDIS, 2002; MAVROPOULOS, BRESIN and KILIARIDIS, 2004, MAVROPOULOS, RIZZOLI and AMMANN, 2007; SHIMOMOTO, CHUNG, IWASAKIHAYASHI et al., 2007).

The conditions of muscle hyperactivity and hypoactivity, associated with an existing hypertrophy and atrophy, justify that the mechanical stress be considered an important regulative factor and determinant for the bone morphology, since the primary stages, as it is responsible for the encouraging the process of bone apposition (ROKX, VAN WILLIGEN and JANSEN, 1984; PAVLIN, DOVE, ZADRO et al., 2000).

Kiliaridis (1986) and Bresin, Bagge and Kiliaridis (2000), collaborated with the aspects discussed in the previous paragraphs on their studies, because they have investigated the feeding of mice with diets of different consistencies and concluded that the food with hard consistency caused more difficulties at chewing due to the greater stress and tension of muscles and teeth, causing increase of bone density in the ramus of the mandible of these animals. While the animals that were fed with soft diet showed decrease of the bone density (KILIARIDIS, 1986; BRESIN, BAGGE and KILIARIDIS, 2000).

The analysis of the anatomy and function of the masticatory muscles and bone structures in different regions of mandible was carried out adopting the most common types of occlusion disorder, the increase of the vertical occlusal dimension and the mandibular retrusion. By using different methods it was possible to observe that the increase of vertical occlusal dimension promotes the muscle hypofunction, resultant of a limited and inefficient chewing capable to cause reduction of the volume of temporalis and masseter muscle fibers and reduction of bone composition from the ramus of the mandible and base regions, insertion places of the masseter muscle (URIBE, STUMP, TIPTON et al., 1992; BRESIN and KILIARIDIS, 2002; SHIMOMOTO, CHUNG, IWASAKI-HAYASHI et al., 2007; CASARIN, BOCALINI, LEITE et al., 2015). Whereas the region of the incisors alveolar processes showed an increase in 
the bone density, what is justified by the fact that the increase of occlusal vertical dimension enable the manipulation of food with the front teeth only, causing greater mechanic stimulus in the region of the alveolar processes, resulting in bone apposition of this region and consequent increase of bone density of this location (CASARIN, BOCALINI, LEITE et al., 2015).

The mandible's retrusive displacement, also evaluated by different techniques showed changes in the morphology of the condylar process, negative influences on the structural characteristics of the temporomandibular joint and mainly of the masticatory muscles (DESAI, JOHNSON, HOWES et al., 1996; CHOLASUEKSA, WARITA and SOMA, 2004; OHMURE, MIYAWAKI, NAGATA et al., 2008).

The retruded mandible was capable to make the incisor teeth incapable to perform its functions, which resulted in a mastication difficulty, increasing the effort of the masseter and temporalis muscles, especially of the masseter muscles. Therefore, it was possible to observe an increase on the volume area of its fibers and in consequence, the increase of bone density in regions of insertion of the masseter muscle, as ramus and base of the mandible, while in the incisors alveolar process the bone density was reduced (CASARIN, BOCALINI, LEITE et al., 2015).

These results were found mostly in studies with animals and in accordance with the study of Ohmure, Miyawaki, Nagata et al. (2008); it can be linked to masticatory system of humans, as the same results were found in similar experimental conditions.

During the last decades, several studies presented differences among the mechanisms in acute and chronic pain. The acute is mainly caused by inflammation in peripheral tissue (peripheral sensitization), whereas chronic pain is the increase in the response of central nervous system (central sensitization) (CAO, XIE, LI et al., 2009).

The disorders of the stomatognathic system are the major causes of chronic orofacial pain (PEREIRA and CONTI, 2001; ALMEIDA, MELLO and IRIKURA., 2005; BOLETACERANTO, ALVES and ALENDE, 2008), what according to Selaimen, Jeronymo, Brilhante et al. (2007), among the possible etiologic factors, the malocclusion is presented with emphasis towards the others. The occlusal changes when initiate pain are considered prevalent risks of disorders of the temporomandibular joint, as well as responsible for the abnormalities of musculoskeletal architecture of the stomatognathic system.

Cao, Xie, Li et al. (2009), verified the relation between malocclusion and masticatory muscle pain in rats through the implantation of crowns of different sizes in the first molar. Therefore, it was observed that the greater the vertical dimension of occlusion produced by the crown, the greater the mechanical hyperalgesia in masticatory muscles. This hyperalgesia persisted even after the external stimulus was removed for three weeks, which is defined by peripheral sensitization. Clinical condition of pain similar to the one found in humans (PEREIRA and CONTI, 2001; ALMEIDA, MELLO and IRIKURA, 2005; BOLETA-CERANTO, ALVES and ALENDE, 2008), once when there is an increase of occlusal vertical dimension, the muscles become atrophied and less required and consequently, somatized with pain, inhibit the process of bone apposition, causing reduction of bone tissue mineral density of mandible (CASARIN, BOCALINI, LEITE et al., 2015).

Considering the discussed aspects, this study highlights the importance of accurate diagnoses, specific care and precautions to the occlusal changes, because they are responsible for causing morphological changes harmful to the stomatognathic system.

\section{Conclusion}

It was possible to conclude that the malocclusion leads morphological and functional changes in the mandible and in the masticatory muscles. It is associated with prevalence of temporomandibular joint disorders. Facts that exacerbate malocclusion as a major factor of chronic pain and deconstructive agent of quality of life in affected individuals.

\section{References}

ALMEIDA, FG., MELLO, EB. and IRIKURA, S. Pharmacological and occlusal therapies in headaches related to temporomandibular disorders. ATM Journal, 2005, vol. IV, p. 22.

AZUMA, S., KOHZUKI, M., SAEKI, S., TAJIMA, M., IGARASHI, K. and SUGAWARA, J. Beneficial effects of orthodontic treatment on quality of life in patients with malocclusion. The Tohoku Journal of Experimental Medicine, 2008, vol. 214, n. 1, p. 39-50. http:// dx.doi.org/10.1620/tjem.214.39. PMid:18212486.

BANI, D. and BERGAMINI, M. Ultrastructural abnormalities of muscle spindles in the rat masseter muscle with malocclusion-induced damage. Histology and Histopathology, 2002, vol. 17, n. 1, p. 45-54. PMid:11813885.

BOLETA-CERANTO, DCF., ALVES, T. and ALENDE, FL. The effect of acupuncture on pain control in dentistry. Arch Health Science, 2008, vol. 12, n. 2, p. 143-148.

BRESIN, A. and KILIARIDIS, S. Dento-skeletal adaptation after biteraising in growing rats with different masticatory muscle capacities. European Journal of Orthodontics, 2002, vol. 24, n. 3, p. 223-237. http://dx.doi.org/10.1093/ejo/24.3.223. PMid:12143087.

BRESIN, A., BAGGE, U. and KILIARIDIS, S. Adaptation of normal and hypofunctional masseter muscle after bite-raising in growing rats. European Journal of Oral Sciences, 2000, vol. 108, n. 6, p. 493-503. http://dx.doi.org/10.1034/j.1600-0722.2000.00915.x. PMid:11153924.

BROWN, JP., JOSSE, RG. and SCIENTIFIC ADVISORY COUNCIL OF THE OSTEOPOROSIS SOCIETY OF CANADA. Clinical practice guidelines for the diagnosis and management of osteoporosis in Canada. Canadian Medical Association Journal, 2002, vol. 167, suplemento 10, p. S1-S34. PMid:12427685.

CAO, Y., XIE, Q., LI, K., LIGHT, AR. and FU, KY. Experimental occlusal interference induces long- term masticatory muscle hyperalgesia in rats. Pain, 2009, vol. 144, n. 3, p. 287-293. http://dx.doi. org/10.1016/j.pain.2009.04.029. PMid:19473767.

CASARIN, CAS., BOCALINI, DS., LEITE, GS., SERRA, AJ., MARCHETTI, PH., ANDRADE, EL., ARSA, G., PACHECO, ME. and CARIA, PHF. Effect of retrusive displacement of the mandible and increase of the oclusal vertical dimension on mandibular bone density and the masticatory muscles of wistar rats. Australian Journal of Basic and Applied Sciences, 2015, vol. 7, n. 13, p. 1-7.

CHOLASUEKSA, P., WARITA, H. and SOMA, K. Alterations of the rat temporomandibular joint in functional posterior displacement of the mandible. The Angle Orthodontist, 2004, vol. 74, n. 5, p. 677 683. PMid:15529504.

DALE, R. Occlusion: the standard of care. Journal - Canadian Dental Association, 2001, vol. 67, n. 2, p. 83-85. PMid:11253294.

DESAI, S., JOHNSON, DL., HOWES, RI. and ROHRER, MD. Changes in the rabbit temporomandibular joint associated with posterior displacement of the mandible. The International Journal of Prosthodontics, 1996, vol. 9, n. 1, p. 46-57. PMid:8630177. 
HILL, PA. and ORTH, M. Bone remodelling. British Dental Journal, 1998, vol. 25, n. 2, p. 101-107. PMid:9668992.

KILIARIDIS, S. Masticatory muscle function and craniofacial morphology. an experimental study in the growing rat fed a soft diet. Swedish Dental Journal, 1986, vol. 36, p. 1-55. PMid:3465055.

KUNII, R., YAMAGUCHI, M., AOKI, Y., WATANABE, A. and KASAI, K. Effects of experimental occlusal hypofunction, and its recovery, on mandibular bone mineral density in rats. European Journal of Orthodontics, 2008, vol. 30, n. 1, p. 52-60. http://dx.doi. org/10.1093/ejo/cjm057. PMid:18024469.

MAVROPOULOS, A., BRESIN, A. and KILIARIDIS, S. Morphometric analysis of the mandible in growing rats with different masticatory functional demands: adaptation to the upper posterior bite block. European Journal of Oral Sciences, 2004, vol. 112, n. 3, p. 259266. http://dx.doi.org/10.1111/j.1600-0722.2004.00129.x. PMid:15154925.

MAVROPOULOS, A., RIZZOLI, R. and AMMANN, P. Different responsiveness of alveolar and tibial bone-to-bone loss stimuli. Journal of Bone and Mineral Research, 2007, vol. 22, n. 3, p. 403-410. http:// dx.doi.org/10.1359/jbmr.061208. PMid:17181394.

MEGHJI, S. Bone remodeling. British Dental Journal, 1992, vol. 172, n. 6, p. 235-242. http://dx.doi.org/10.1038/sj.bdj.4807835. PMid:1554530.

MIEHE, B., FANGHANEL, J., KUBEIN-MEESENBURG, D., NAGERL, H. and SCHWESTKA-POLLY, R. Masticatory musculature under altered occlusal relationships - a model study with experimental animals. Annals of Anatomy, 1999, vol. 181, n. 1, p. 37-40. http:// dx.doi.org/10.1016/S0940-9602(99)80084-3. PMid:10081556.

MOLINA, OF. Fisiopatologia crânio mandibular: oclusão e ATM. São Paulo: Pancast, 1989, p. 595.

OHMURE, H., MIYAWAKI, S., NAGATA, J., IKEDA, K., YAMASAKI, $\mathrm{K}$. and AL-KALALY, A. Influence of forward head posture on condylar position. Journal of Oral Rehabilitation, 2008, vol. 35, n. 11, p. 795-800. http://dx.doi.org/10.1111/j.1365-2842.2007.01834.x. PMid:18808377.

PAVLIN, D., DOVE, SB., ZADRO, R. and GLUHAK-HEINRICH, J. Mechanical loading simulates differentiation of periodontal osteoblasts in a mouse osteoinduction model: effect on type I collagen and alkaline phosphatase genes. Calcified Tissue International, 2000, vol. 67, n. 2, p. 163-172. http://dx.doi.org/10.1007/s00223001105. PMid:10920222.
PEREIRA, JR. and CONTI, PCR. Occlusal alterations and its relation to the temporomandibular disorders. Journal of Dentristy College of Bauru, 2001, vol. 9, n. 3-4, p. 139-144.

POSSELT, U. Fisiologia de la oclusion y rehabilitacion. Barcelona: Editora Mallat Desplats, 1973, p. 352.

ROKX, JT., VAN WILLIGEN, JD. and JANSEN, HW. Muscle fibre types and muscle spindles in the jaw musculature of the rat. Archives of Oral Biology, 1984, vol. 29, n., 1, p. 25-31. http://dx.doi. org/10.1016/0003-9969(84)90038-4. PMid:6229238.

SELAIMEN, CM., JERONYMO, JC., BRILHANTE, DP., LIMA, EM., GROSSI, PK. and GROSSI, ML. Occlusal risk factors for temporomandibular disorders. The Angle Orthodontist, 2007, vol. 77, n. 3, p. 471-477. http://dx.doi.org/10.2319/00033219(2007)077[0471:ORFFTD]2.0.CO;2. PMid:17465655.

SHIMOMOTO, Y., CHUNG, C., IWASAKI-HAYASHI, J., MURAMOTO, Y. and SOMA, K. Effects of occlusal stimuli on alveolar/ jaw bone formation. Journal of Dental Research, 2007, vol. 86, n. 1, p. 47-51. http://dx.doi.org/10.1177/154405910708600107. PMid:17189462.

URIBE, JM., STUMP, CS., TIPTON, CM. and FREGOSI, RF. Influence of exercise training on the oxidative capacity of rat abdominal muscle. Respiration Physiology, 1992, vol. 88, n. 1-2, p. 171-180. http://dx.doi.org/10.1016/0034-5687(92)90038-X. PMid:1626136.

VLASIADIS, KZ., DAMILAKIS, J., VELEGRAKIS, GA., SKOUTERIS, CA., FRAGOULI, I., GOUMENOU, A., MATALLIOTAKIS, J. and KOUMANTAKIS, EE. Relationship between BMD, dental panoramic radiographic findings and biochemical markers of bone turnover in diagnosis of osteoporosis. Maturitas, 2008, vol. 59, n. 3 , p. 226-233. http://dx.doi.org/10.1016/j.maturitas.2008.01.006. PMid:18342460.

WINARAKWONG, L., MURAMOTO, T., SOMA, K. and TAKANO, Y. Age-related changes and the possible adaptability of rat jaw muscle spindles: immunohistochemical and fine structural studies. Archives of Histology and Cytology, 2004, vol. 67, n. 3, p. 227-240. http:// dx.doi.org/10.1679/aohc.67.227. PMid:15570888.

ZHANG, M., MCGRATH, C. and HÄGG, U. The impact of malocclusion and its treatment on quality of life: a literature review. International Journal of Paediatric Dentistry, 2006, vol. 16, n. 6, p. 381-387. http://dx.doi.org/10.1111/j.1365-263X.2006.00768.x. PMid:17014535. 